\title{
Selection of processing tomato genotypes with high acyl sugar content that are resistant to the tomato pinworm
}

\author{
D.M. Dias, J.T.V. Resende, M.V. Faria, L.K.P. Camargo, R.R. Chagas \\ and I.P. Lima \\ Departamento de Agronomia, Universidade Estadual do Centro-Oeste, \\ Campus CEDETEG, Guarapuava, PR, Brasil \\ Corresponding author: J.T.V. Resende \\ E-mail: jresende@unicentro.br
}

Genet. Mol. Res. 12 (1): 381-389 (2013)

Received April 25, 2012

Accepted October 26, 2012

Published February 8, 2013

DOI http://dx.doi.org/10.4238/2013.February.8.2

\begin{abstract}
Acyl sugars are allelochemicals present at high concentrations in leaves of accessions of the wild tomato Solanum pennellii; they confer resistance to a large number of arthropod pests, including the tomato pinworm, Tuta absoluta (Lepidoptera, Gelechiidae). Accession 'LA716', with high contents of acyl sugars in the leaves, was used as a source of resistance to start a genetic breeding program of processing cultivated tomato, S. lycopersicum. We selected plants of the $\mathrm{F}_{2}$ generation of an interspecific cross (S. lycopersicum cv. 'Redenção' x S. pennellii 'LA716') for extremes of concentrations (high and low) of acyl sugars in the leaves and evaluated the resistance of selected genotypes to the tomato pinworm, compared with plants of the parental and $F_{1}$ generations. The concentrations of acyl sugars present in the genotypes selected for high contents were close to those of $S$. pennellii 'LA 716', while the genotypes with low concentrations of acyl sugars were close to cultivar 'Redenção'. The $\mathrm{F}_{1}$ hybrid ('Redenção' $x$ 'LA716') had intermediate concentrations of acyl sugars, but was closer to Redenção, indicating that the inheritance of this type of
\end{abstract}


character is due to a recessive major gene, along with minor genes with additive effects. There was a direct association between high contents of acyl sugars and non-preference for oviposition and suppression of larval development, indicating that the allelochemical acts through mechanisms of non-preference for oviposition and through antibiosis. Genotypes with high contents of acyl sugars were more effective in reducing the damage caused by the tomato pinworm. Genotypes RVTA-2010pl\#94 and RVTA-2010pl\#31, selected for high contents of acyl sugars, showed a good level of resistance to T. absoluta, similar to the wild genotype LA716. These genotypes are promising for use in a breeding program for developing commercial processing tomatoes.

Key words: Solanum pennellii; Allelochemical; Tuta absoluta; Pest resistance

\section{INTRODUCTION}

The world's largest tomato (Solanum lycopersicum) producers are the United States (32.04\%), China (16.61\%), Italy (13.58\%), and Spain (6.28\%) (WPTC - World Processing Tomato Council, 2011). In Brazil, tomatoes for industrial processing accounted for approximately $49 \%$ of total production in 2010 , making this country the fifth largest producer $(4.9 \%)$ in the world. That year, the tomato crop in Brazil reached an area of 21,258 ha with an average yield of 85.4 tons/ha, an increase of $40 \%$ in total average yield of tomatoes both for industrial processing and fresh consumption (IBGE - Instituto Brasileiro de Geografia Estatística, 2011).

The annual industrialized volume of tomato is the highest of all vegetables worldwide, and tomato uses the second highest amount of acreage for cultivation. In Brazil, tomato crops represent $20 \%$ of vegetable crops, occupying $7.56 \%$ of the area available for cultivation and generating an estimated 610,250 agricultural production jobs (EMBRAPA - Empresa Brasileira de Pesquisa Agropecuária, 2008).

Generally, the excessive application of broad-spectrum chemicals to control pests and diseases represents approximately $30 \%$ of the total financial cost of growing tomato crops (EMBRAPA, 2009). According to the ANVISA - Agência Nacional de Vigilância Sanitária (2010), tomato retains some of the highest amounts of pesticide residue as a contaminant, increasing the risk of health problems for producers and consumers and harming the environment.

The processing tomato crop in Brazil is concentrated in the midwest and southeast; however, it has increased considerably in the south - specifically in the State of Paraná. This expansion has intensified plant health problems, leading farmers to make use of pesticides to ensure production. The tomato pinworm (Tuta absoluta Meyr.) stands out among arthropods pests that cause the most damage and are responsible for the high demand for pesticides.

Integrated pest management is central to reducing the problems caused by the tomato pinworm. Genetic resistance is an important strategy, although its success in commercial cultivars is still modest because the levels of resistance shown by current commercial cultivars of processing tomatoes are not high enough.

Wild tomato species such as Solanum pennellii have been widely used as a source of 
resistance to pests and diseases in breeding tomato cultivars. Accessions of $S$. pennellii have high levels of resistance to a large number of arthropod pests, including the tomato pinworm (Gonçalves et al., 2006; Saeidi et al., 2007; Pereira et al., 2008; Resende et al., 2006, 2008, 2009; Gonçalves Neto et al., 2010). The resistance of S. pennellii has been associated with the presence of allelochemicals called acyl sugars, which are esters of fatty acids. These allelochemicals may act by preventing oviposition and feeding by arthropods or even by exerting deleterious effects on their development during certain phases. Unlike S. pennellii, current commercial cultivars of tomatoes lack high acyl sugar content, whereas $\mathrm{F}_{1}$ plants from a cross between S. lycopersicum and S. pennellii have moderate contents (Resende et al., 2002).

Obtaining tomato plants with high acyl sugar content in the leaves and high levels of resistance to major pests is of great importance in the management of cultures in which pest control has been achieved mainly through chemical means. Therefore, this study aimed to select plants of the $\mathrm{F}_{2}$ generation of an interspecific cross (S. lycopersicum cv. 'Redenção' x $S$. pennellii 'LA716') with high acyl sugar content in the leaflets and to evaluate the resistance of selected genotypes to tomato pinworm.

\section{MATERIAL AND METHODS}

\section{Obtaining populations and selecting plants according to acyl sugar content in leaflets}

The experiment was performed in a greenhouse in the Department of Agronomy of the Universidade Estadual do Centro Oeste do Paraná, Guarapuava, Paraná State $\left(25^{\circ} 23^{\prime} 01^{\prime \prime} \mathrm{S}\right.$ latitude, $51^{\circ} 29^{\prime} 46^{\prime \prime} \mathrm{W}$ longitude, $1100 \mathrm{~m}$ altitude). The $\mathrm{F}_{2}$ population was obtained from seeds of the selfing of $\mathrm{F}_{1}$ plants from the interspecific cross between $S$. pennellii 'LA716' (wild accession with high acyl sugar content and resistance to pests) and S. lycopersicum 'Redenção' (commercial cultivar developed for industrial processing with low acyl sugar content). It has determinate growth habit and resistance to tospovirus and geminivirus. Fruits are elongated, with an average weight of $110 \mathrm{~g}$, and the number of loci range from two to three. The fruits have good firmness, a uniform ripening pattern, and intense and uniform red pulp. The harvest starts 100 to 110 days after sowing (Ferraz et al., 2003).

Acyl sugar content was quantified in 400 plants of the $F_{2}$ population by analyzing three samples of expanded leaflets of the upper third of the plants using a method described by Resende et al. (2002). The plants were selected for contrasting acyl sugar content in the leaflets (high and low), cloned via rooting of axillary shoots, and kept in a greenhouse.

After cloning, the selected $\mathrm{F}_{2}$ plants, $\mathrm{F}_{1}$ plants ( $\mathrm{S}$. lycopersicum 'Redenção' x $S$. pennellii 'LA716' with intermediate contents of acyl sugars), and parent plants were transplanted into polyethylene pots with a volume of $5 \mathrm{dm}^{3}$ and filled with the commercial substrate Plant$\max ^{\circledR}$ (Eucatex Agro Florestal Ltda., São Paulo, Brazil) and soil in a 1:1 ratio. The pots were placed in a greenhouse until the plants reached the growth stage of pre-flowering and were then submitted to infestation with tomato pinworm.

\section{Obtaining and maintaining the T. absoluta population}

T. absoluta adults were collected in fields in the city of Faxinal, PR, Brazil (2359'59" south latitude, $51^{\circ} 19^{\prime} 15^{\prime \prime}$ west longitude, $840 \mathrm{~m}$ altitude). The insects were bred in tomato plants 
of the cultivar 'Santa Clara' (highly susceptible) and placed in cages $(1.0 \times 1.0 \times 1.20 \mathrm{~m}$ and coated with anti-aphids mash) inside a separated greenhouse to maintain a continuously high pest population. Before starting the bioassay, insects were classified by sex in the laboratory (Coelho and França, 1987) for an infestation of the studied genotypes in the proportion of 1 male:1.32 females per plant (Haji et al., 1988). Nine males and 12 females were initially placed in each cage.

\section{Bioassay for evaluating plants for resistance to T. absoluta}

The selected genotypes with contrasting acyl sugar content were evaluated for response to tomato pinworm infestation in an experiment conducted from November 2011 to January 2012. The evaluation of the resistance was performed in a randomized block design with three replications (three cages). An $\mathrm{F}_{2}$ plant of each selected genotype (for high or low acyl sugar content), an $F_{1}$ plant, and a plant of each parent were placed in each cage. The genotypes were evaluated at three times according to a scale proposed by Barbosa (1994) and Labory (1996) for the parameters overall plant damage, leaflet lesion type, and the percent of leaflets attacked.

Scores for overall plant damage were as follows: 0 , no damage ( $0 \%$ damage); 1 , small and few lesions ( 0.1 to $5 \%$ damage); 2 , small and non-coalescent lesions (5.1 to $20 \%$ damage); 3 , medium and large lesions (20.1 to $50 \%$ damage); 4 , several and highly coalescent lesions ( 50.1 to $80 \%$ damage), and 5, totally deformed (above $80.1 \%$ damage). Scores for leaflet lesion types were as follows: 0 , no injuries in leaflets; 1 , small and few lesions; 2 , few small and medium lesions often located at the border of the leaflets; 3 , medium and large lesions, numerous and coalescing, deformed leaflets; 4 , large coalescing lesions, completely deformed leaves, and 5, lesions damaging the whole leaflet. Scores for percent of leaflets attacked were as follows: 0 , no leaflets attacked; $1,0.1$ to $5 \%$ of leaflets attacked; $2,5.1$ to $20 \%$ of leaflets attacked; 3, 20.1 to $50 \%$ of leaflets attacked; 4,51 to $80 \%$ of leaflets attacked, and 5, more than $80 \%$ of leaflets attacked.

The oviposition of tomato pinworm on the leaflets was evaluated 10, 30, and 50 days after infestation. The eggs were counted in three young and expanded leaflets of the same age and with similar area on the upper third of each plant using a magnifying glass. These leaflets were identified at each assessment, which was later used to estimate the number of larvae. The number of larvae was obtained 30,50 , and 70 days after infestation. The average temperature and relative humidity throughout the experiment ranged from $18.3^{\circ}$ to $34.7^{\circ} \mathrm{C}$ and from 82.0 to $100 \%$, respectively.

Data were submitted to analysis of variance and means comparison with the Tukey test using the SISVAR statistical program (Ferreira, 2008) and Pearson's correlations were estimated to verify the association among traits.

\section{RESULTS AND DISCUSSION}

Genotypes selected for high acyl sugar content showed values close to that of S. pennellii 'LA 716', whereas genotypes selected for low acyl sugar content had levels close to those of 'Redenção' (Table 1). The F $\mathrm{F}_{1}$ hybrid ('Redenção' x 'LA716') showed intermediate acyl sugar content with values that tended to be closer to those of the cultivate 'Redenção'. This result is due to the type of inheritance involved in the control of this trait to deal with monogenic recessive genes with minor additive effects (Resende et al., 2002; Gonçalves et al., 2006). 
Table 1. Mean number of eggs and number of larvae present in leaflets of processing tomato genotypes selected for contrasting acyl sugar contents and submitted to infestation of Tuta absoluta.

\begin{tabular}{|c|c|c|c|c|c|c|c|}
\hline \multirow[t]{3}{*}{ Genotype } & \multirow{3}{*}{$\begin{array}{l}\text { Acyl sugar content } \\
\quad\left(\mathrm{nmol} / \mathrm{cm}^{2}\right)\end{array}$} & \multicolumn{3}{|c|}{ No. of eggs } & \multicolumn{3}{|c|}{ No. of larvae } \\
\hline & & \multicolumn{3}{|c|}{ Evaluation } & \multicolumn{3}{|c|}{ Evaluation } \\
\hline & & $1 \mathrm{st}$ & $2 \mathrm{nd}$ & $3 \mathrm{rd}$ & $1 \mathrm{st}$ & 2 nd & $3 \mathrm{rd}$ \\
\hline LA716 (S. pennellii) & 214.54 & $0.75^{\mathrm{a}}$ & $0.75^{\mathrm{a}}$ & $0.50^{\mathrm{a}}$ & $0.00^{\mathrm{a}}$ & $0.50^{\mathrm{a}}$ & $0.75^{\mathrm{a}}$ \\
\hline RVTA-2010pl\#94 (alto) & 179.89 & $1.50^{\mathrm{a}}$ & $1.25^{\mathrm{a}}$ & $1.75^{\mathrm{a}}$ & $0.25^{\mathrm{a}}$ & $0.75^{\mathrm{a}}$ & $1.25^{\mathrm{a}}$ \\
\hline $\mathrm{F}_{1}$ (Redenção x LA716) & 62.83 & $2.75^{\mathrm{ab}}$ & $4.25^{\mathrm{b}}$ & $1.00^{\mathrm{a}}$ & $0.50^{\mathrm{ab}}$ & $1.75^{\mathrm{a}}$ & $1.50^{\mathrm{a}}$ \\
\hline RVTA-2010pl\#75 (high) & 196.81 & $6.00^{\mathrm{cd}}$ & $4.00^{\mathrm{b}}$ & $0.75^{\mathrm{a}}$ & $0.75^{\mathrm{ab}}$ & $2.50^{\mathrm{ab}}$ & $2.00^{\mathrm{a}}$ \\
\hline RVTA-2010pl\#83 (high) & 221.53 & $1.75^{\mathrm{a}}$ & $2.75^{\mathrm{ab}}$ & $1.00^{\mathrm{a}}$ & $0.75^{\mathrm{ab}}$ & $1.00^{\mathrm{a}}$ & $0.75^{\mathrm{a}}$ \\
\hline RVTA-2010pl\#31 (high) & 196.33 & $4.00^{\mathrm{bc}}$ & $1.75^{\mathrm{a}}$ & $0.75^{\mathrm{a}}$ & $0.75^{\mathrm{ab}}$ & $1.50^{\mathrm{a}}$ & $0.75^{\mathrm{a}}$ \\
\hline RVTA-2010pl\#33 (low) & 40.92 & $6.25^{\mathrm{cd}}$ & $4.75^{\mathrm{bc}}$ & $0.50^{\mathrm{a}}$ & $1.50^{\mathrm{c}}$ & $2.75^{\mathrm{ab}}$ & $1.75^{\mathrm{a}}$ \\
\hline RVTA-2010pl\#39 (low) & 42.16 & $10.25^{\mathrm{d}}$ & $4.75^{\mathrm{bc}}$ & $0.25^{\mathrm{a}}$ & $1.50^{\mathrm{c}}$ & $2.50^{\mathrm{ab}}$ & $1.75^{\mathrm{a}}$ \\
\hline Redenção (S. lycopersicum) & 58.34 & $12.25^{\mathrm{e}}$ & $5.00^{c}$ & $1.00^{\mathrm{a}}$ & $2.00^{\mathrm{d}}$ & $5.75^{\mathrm{b}}$ & $1.50^{\mathrm{a}}$ \\
\hline $\mathrm{CV} \%$ & & 25.97 & 29.31 & 21.79 & 21.72 & 23.47 & 23.80 \\
\hline
\end{tabular}

Means followed by the same superscript letters in columns do not differ by the Tukey test $(\alpha=0.05)$. CV\% $=$ coefficient of variation.

Oviposition and number of larvae were affected by the acyl sugars present in the leaflets, and the genotypes selected for high acyl sugar content had a lower number of eggs and larvae at the first two evaluation times. An exception was RTVA-2010pl\#75, which did not differ statistically from genotypes selected for low acyl sugar content (RVTA-2010pl\#33 and RVTA-2010\#p139) and had a high number of larvae and eggs on its leaflets. Similar results were obtained by Gonçalves Neto et al. (2010), who found that oviposition in tomato pinworm did not differ between genotypes with high and low acyl sugar content. This result can be explained by the presence of other potential allelochemicals with antagonistic effects similar to those caused by acyl sugars. Maluf et al. (2010) have suggested that this divergence is normal, because resistance factors other than acyl sugars present in $S$. pennellii may not have been recovered through selection.

The results indicate that the allelochemical acts presumably via two mechanisms of resistance, non-preference for oviposition and antibiosis, which prevents larval development and egg hatching. A significant negative correlation $(r=-0.69$ and $r=-0.71)$ was found between acyl sugar content and oviposition and number of larvae, respectively. Similar results have been reported by Resende et al. (2006), Gonçalves et al. (2008), Gonçalves Neto (2008), and Maciel et al. (2011) with respect to the oviposition of T. absoluta in advanced genotypes with high acyl sugar content. Gonçalves Neto et al. (2010) have also observed non-preference and antibiosis in advanced tomato genotypes for fresh consumption.

We found no statistically significant differences between genotypes with either trait in the third evaluation (50 days after infestation). Given that the same leaflet was assessed in all evaluations, we emphasize that these results were expected, because the genotypes with low levels of acyl sugars displayed completely injured leaflets, which prevented oviposition and, consequently, the development of larvae owing to a shortage of food.

Genotypes RVTA-2010pl\#94, RVTA-2010pl\#83, and RVTA-2010pl\#31, which were selected for high acyl sugar content, did not differ from the wild accession 'LA716', and those selected for low acyl sugar content did not differ from 'Redenção' with respect to oviposition and number of larvae in the three evaluations (Figure 1). These results are consistent with those obtained by Gonçalves Neto et al. (2010) for advanced generations of fresh market to- 
matoes selected for high acyl sugar content and by Maluf et al. (2010), who associated lower T. absoluta oviposition with higher acyl sugar content in genotypes from advanced backcross generations. However, our results contrast with those obtained by Resende et al. (2006), who observed no significant differences for oviposition in tomato genotypes selected for high acyl sugar content. This difference may be related to instability in the early segregating generations masked from the interspecific cross, probably owing to the great influence of various genotypic backgrounds (Gonçalves Neto et al., 2010).

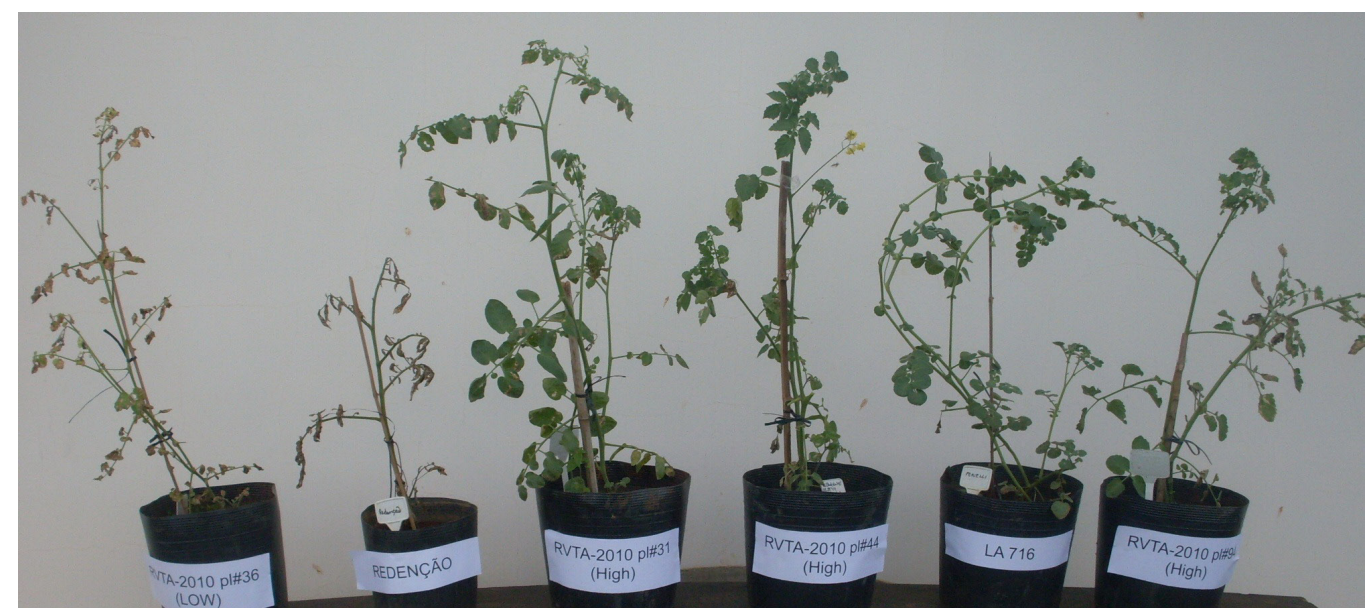

Figure 1. Overall damage caused by tomato pinworm 50 days after infestation in genotypes RVTA_2010\#36 (low acyl sugar content), 'Redenção' (Solanum lycopersicom), RVTA_2010\#31 (high acyl sugar content), RVTA_2010\#44 (high acyl sugar content), LA716' (Solanum pennellii), and RVTA_2010\#94 (high acyl sugar content).

According to data of overall plant damage, leaflet lesion types, and percent of leaflets attacked, genotypes with high acyl sugar content more effectively avoided damage caused by the tomato pinworm (Table 2). Considering overall plant damage and leaflet lesion type, we found that the genotypes RVTA-2010pl\#94 and RVTA-210pl\#31 did not differ from 'LA716' in damage reduction for both traits regardless of evaluation period; therefore, these genotypes are quite promising for the continuation of breeding programs. The other genotypes selected for high acyl sugar content (RVTA-2010pl\#83 and RVTA-2010pl\#75) in the first evaluation of the same characteristics did not differ statistically from selected plants with low acyl sugar content (RVTA-2010pl\#33 and RVTA-2010pl\#39), which consequently did not differ from control and female parents (cultivar 'Redenção') and F 1 plants ('Redenção' x 'LA716'). However, at the second and third evaluations, damage to genotypes with low acyl sugar content was higher than that in genotypes selected for high content.

Regarding the percent of leaflets attacked at the third evaluation, we found statistical difference between genotypes RVTA-2010pl\#94 and RVTA-2010pl\#31, selected for high allelochemical content, compared with those selected for low content. At the first and second evaluations, these genotypes differed only from cultivar 'Redenção', probably owing to the genetic control of the acyl sugars synthesis - i.e., a single major gene with the possibility of other modifier genes with additive effects. Therefore, even genotypes with low acyl sugar content may 
have small concentrations of other allelochemicals that at first might contribute to reducing pest damage. This fact was apparent given the behavior of the cultivar 'Redenção' and the $\mathrm{F}_{1}$ plants ('Redenção’x 'LA716’), which have low acyl sugar content and behaved as susceptible plants.

Table 2. Means of scores for overall plant damage, leaflet lesion type, and percent of leaflets attacked in processing tomato genotypes selected for contrasting acyl sugar contents in the leaflets and submitted to infestation of Tuta absoluta.

\begin{tabular}{|c|c|c|c|c|c|c|c|c|c|}
\hline \multirow[t]{3}{*}{ Genotype } & \multirow{2}{*}{\multicolumn{3}{|c|}{$\frac{\text { Overall plant damage }}{\text { Evaluation }}$}} & \multicolumn{3}{|c|}{ Leaflet lesion type } & \multicolumn{3}{|c|}{ Percent of leaflets attacked } \\
\hline & & & & & valuation & & \multicolumn{3}{|c|}{ Evaluation } \\
\hline & $1 \mathrm{st}$ & 2nd & $3 \mathrm{rd}$ & $1 \mathrm{st}$ & $2 \mathrm{nd}$ & $3 \mathrm{rd}$ & $1 \mathrm{st}$ & 2nd & $3 \mathrm{rd}$ \\
\hline LA716 (S. pennellii $)$ & $1.43^{\mathrm{a}}$ & $1.13^{\mathrm{a}}$ & $2.18^{\mathrm{a}}$ & $1.60^{\mathrm{a}}$ & $1.50^{\mathrm{a}}$ & $2.56^{\mathrm{a}}$ & $1.00^{\mathrm{a}}$ & $1.06^{\mathrm{a}}$ & $2.25^{\mathrm{a}}$ \\
\hline RVTA-2010pl\#94 (high) & $1.62^{\mathrm{a}}$ & $2.06^{\mathrm{a}}$ & $2.00^{\mathrm{a}}$ & $1.81^{\mathrm{a}}$ & $1.94^{\mathrm{a}}$ & $2.50^{\mathrm{a}}$ & $1.75^{\mathrm{ab}}$ & $2.25^{\mathrm{ab}}$ & $2.19^{\mathrm{a}}$ \\
\hline F (Redenção x LA716) & $3.12^{\mathrm{ab}}$ & $3.32^{\mathrm{bc}}$ & $2.69^{\mathrm{abc}}$ & $3.62^{\mathrm{c}}$ & $3.81^{\text {cd }}$ & $3.19^{\mathrm{abc}}$ & $3.43^{\mathrm{bc}}$ & $3.38^{\mathrm{bc}}$ & $2.88^{\mathrm{ab}}$ \\
\hline RVTA-2010pl\#75 (high) & $2.62^{\mathrm{ab}}$ & $3.44^{\mathrm{bc}}$ & $2.75^{\mathrm{abc}}$ & $2.93^{\mathrm{ab}}$ & $3.62^{\mathrm{cd}}$ & $2.94^{\mathrm{abc}}$ & $2.38^{\mathrm{abc}}$ & $3.38^{\mathrm{bc}}$ & $3.00^{\mathrm{ab}}$ \\
\hline RVTA-2010pl\#83 (high) & $1.87^{\mathrm{a}}$ & $2.44^{\mathrm{ab}}$ & $2.63^{\mathrm{ab}}$ & $2.06^{\mathrm{ab}}$ & $2.50^{\mathrm{abc}}$ & $2.68^{\mathrm{a}}$ & $1.81^{\mathrm{ab}}$ & $2.56^{\mathrm{abc}}$ & $2.75^{\mathrm{ab}}$ \\
\hline RVTA-2010pl\#31 (high) & $1.50^{\mathrm{a}}$ & $2.19^{\mathrm{ab}}$ & $2.56^{\mathrm{ab}}$ & $1.87^{\mathrm{a}}$ & $1.81^{\mathrm{a}}$ & $2.87^{\mathrm{ab}}$ & $3.06^{\mathrm{bc}}$ & $1.69^{\mathrm{ab}}$ & $2.31^{\mathrm{a}}$ \\
\hline RVTA-2010pl\#33 (low) & $2.87^{\mathrm{ab}}$ & $3.50^{\mathrm{c}}$ & $3.75^{\text {bcd }}$ & $3.31^{\mathrm{b}}$ & $3.37^{\mathrm{bed}}$ & $4.00^{\text {bed }}$ & $3.31^{\mathrm{bc}}$ & $3.44^{\mathrm{bc}}$ & $3.94^{\mathrm{bc}}$ \\
\hline RVTA-2010pl\#39 (low) & $2.812^{\mathrm{ab}}$ & $3.13^{\mathrm{bc}}$ & $4.00^{\mathrm{cd}}$ & $3.37^{\mathrm{bc}}$ & $3.56^{\mathrm{cd}}$ & $4.19^{\mathrm{cd}}$ & $3.00^{\mathrm{abc}}$ & $3.38^{\mathrm{bc}}$ & $3.75^{\mathrm{bc}}$ \\
\hline Redenção (S. lycopersicum) & $3.93^{\mathrm{b}}$ & $4.19^{\mathrm{c}}$ & $4.81^{\mathrm{d}}$ & $3.87^{\mathrm{d}}$ & $4.36^{\mathrm{d}}$ & $4.88^{\mathrm{d}}$ & $3.93^{\mathrm{c}}$ & $4.31^{\mathrm{c}}$ & $4.78^{\mathrm{c}}$ \\
\hline $\mathrm{CV} \%$ & 34.87 & 21.89 & 17.68 & 32.78 & 22.01 & 15.82 & 32.09 & 27.20 & 18.46 \\
\hline
\end{tabular}

Means followed by the same superscript letters in columns do not differ by the Tukey test $(\alpha=0.05)$. CV\% $=$ coefficient of variation.

Negative and significant correlations between acyl sugar content and overall plant damage $(r=-0.80)$, leaflet lesion type $(r=-0.86)$, and percent of leaflets attacked $(r=-083$; Table 3) confirm the effects of high allelochemical content in resistance to tomato pinworm. The number of eggs had positive and significant correlations with the number of larvae $(\mathrm{r}=$ $0.88)$, overall plant damage $(r=0.85)$, leaflet lesion type $(r=0.84)$, and percent of leaflets attacked $(r=0.78)$. The number of larvae also had positive and significant estimates of correlation with overall plant damage $(r=0.96)$, leaflet lesion type $(r=0.92)$, and percent of leaflets attacked $(r=0.94)$. Person's correlation estimates between plant damage scores were also positive and significant (Table 3). These results suggest direct influence of one trait on another - i.e., high oviposition results in the largest number of larvae and consequently greater damage to leaves and plants.

Table 3. Estimates of Pearson's correlations between the traits evaluated in processing tomato genotypes selected for contrasting contents of acyl sugars in the leaflets submitted to infestation of Tuta absoluta.

\begin{tabular}{|c|c|c|c|c|c|}
\hline & (1) & (2) & (3) & (4) & $(5)$ \\
\hline (1) Acyl sugar content & - & - & - & - & - \\
\hline (2) Number of eggs & $-0.69 *$ & - & - & - & - \\
\hline (3) Number of larvae & $-0.71 *$ & $0.88 * *$ & - & - & - \\
\hline (4) Overall plant damage & $-0.80 * *$ & $0.85 * *$ & $0.96 * *$ & - & - \\
\hline (5) Leaflet lesion type & $-0.86 * *$ & $0.84 * *$ & $0.92 * *$ & $0.98 * *$ & - \\
\hline (6) Percent of leaflets attacked & $0.83^{*}$ & $0.78^{*}$ & $0.94 * *$ & $0.99 * *$ & $0.89 * *$ \\
\hline
\end{tabular}

**, * Significant at 5 and $1 \%$, respectively, by the $t$-test.

All of the results obtained in this study confirm the inferences of other authors (Saeidi et al., 2007; Resende et al., 2006, 2008; Pereira et al., 2008; Gonçalves Neto, 2008, 2010; 
Maluf et al., 2010; Maciel et al., 2011) that the acyl sugars from 'LA716' (S. pennellii) are the main provider of pest resistance when found in high content in the leaflets and that indirect selection for high acyl sugar content was satisfactory for obtaining tomato genotypes with pest resistance. In addition to being an important component of resistance to T. absoluta, acyl sugars have a simple inheritance (Resende et al., 2002; Gonçalves et al., 2007) that is essentially monogenic with modifier genes with additive effects, which makes their introduction particularly easy in elite tomato lines.

Genotypes RVTA-2010pl\#94 and RVTA-2010pl\#31, selected for high acyl sugar content, showed a level of resistance to T. absoluta similar to that of wild genotype 'LA716'. These genotypes are promising for use in backcrosses in processing tomato breeding programs.

\section{ACKNOWLEDGMENTS}

We thank Fundação Araucária de Apoio ao Desenvolvimento Científico e Tecnológico do Paraná for financial support, Conselho Nacional de Desenvolvimento Científico e Tecnológico (CNPq) for Research Incentive scholarships and Coordenação de Aperfeiçoamento de Pessoal de Nível Superior (CAPES) for Master's scholarship.

\section{REFERENCES}

ANVISA - Agência Nacional de Vigilância Sanitária (2010). ANVISA: Agrotóxicos no Brasil. Avaliable at [http://www. anvisa.gov.br]. Accessed April 10, 2011.

Barbosa LV (1994). Controle Genético e Mecanismos de Resistência em Lycopersicon spp à Traça do Tomateiro (Scrobipalpuloides absoluta (Meyrick, 1917) (Lep. Gelechiidae)). Master's thesis, Escola Superior de Agricultura de Lavras, Lavras.

Coelho MCF and França FH (1987). Biologia, quetotaxia da larva e descrição da pupa e adulto da traça-do-tomateiro. Pesq. Agrop. Bras. 22: 129-135.

EMBRAPA - Empresa Brasileira de Pesquisa Agropecuária (2008). Situação da Produção de Hortaliças no Brasil. Available at [http://www.cnph.embrapa.br/paginas/hortalicas_em_numeros/hortalicas_em_numeros.htm]. Accessed September 15, 2011.

EMBRAPA - Empresa Brasileira de Pesquisa Agropecuária (2009). Cultivo de Tomate para Industrialização: Importância Econômica. Available at [http://sistemasdeproducao.cnptia.embrapa.br/FontesHTML/Tomate/TomateIndustrial_2ed/ importancia.htm]. Accessed September 15, 2011.

Ferraz E, Resende LV, Lima GSA, Silva MCL, et al. (2003). Redenção: nova cultivar de tomate para a indústria resistente a geminivírus e tospovírus. Hort. Bras. 21: 578-580.

Ferreira DF (2008). SISVAR: um programa para análises e ensino de estatística. Rev. Cient. Symp. 6: 36-41.

Gonçalves LD, Maluf WR, Cardoso MG, Resende JTV, et al. (2006). Zingibereno, tricomas foliares e sua ação na repelência a Tetranychus evansi em tomateiros derivados do cruzamento Lycopersicon esculentum $\mathrm{x}$ L. hirsutum var. hirsutum. Pesq. Agrop. Bras. 41: 267-273.

Gonçalves LD, Maluf WR, Cardoso MG, Gomes LAA, et al. (2007). Herança de acilaçúcares em genótipos de tomateiro provenientes de cruzamento interespecífico. Pesq. Agrop. Bras. 42: 699-705.

Gonçalves LS, Rodrigues R, Amaral AT Jr, Karasawa M, et al. (2008). Comparison of multivariate statistical algorithms to cluster tomato heirloom accessions. Genet. Mol. Res. 7: 1289-1297.

Gonçalves Neto AC (2008). Seleção para teor de acilaçucar nas folhas em tomateiros com qualidade comercial confere resistência à traça (Tuta absoluta). Master's thesis, Universidade Federal de Lavras, Lavras.

Gonçalves Neto AC, Silva VF, Maluf WR, Maciel GM, et al. (2010). Resistência à traça-do-tomateiro em plantas com altos teores de acilaçúcares nas folhas. Hort. Bras. 28: 203-208.

Haji FNP, Parra JRP, Silva JP and Batista JGS (1988). Biologia da traça do tomateiro sob condições de laboratório. Pesq. Agrop. Bras. 23: 107-110.

IBGE - Instituto Brasileiro de Geografia e Estatística (2011). Sistema IBGE de Recuperação Automática, SIDRA. Produção Agrícola Municipal 2011. Available at [http://ibge.gov.br/home/estatistica/economia/pam]. Accessed September 23, 
2011.

Labory CR (1996). Repetibilidade, herdabilidade no sentido restrito e mecanismo de resistência do teor do aleloquímico 2- Tridecanona em Lycopersicon spp. à traça do tomateiro Scrobipalpuloides absoluta (Meyrick, 1917) Lepdoptera - Gelechidae. Master's thesis, Universidade Federal de Lavras, Lavras.

Maciel GM, Maluf WR, Silva VF, Gonçalves Neto AC, et al. (2011). Híbridos pré-comerciais resistentes a Tuta absoluta obtidos de linhagem de tomateiro rica em acilaçúcares. Hort. Bras. 29: 151-156.

Maluf WR, Maciel GM, Gomes LAA, Cardoso MG, et al. (2010). Broad-spectrum arthropod resistance in hybrids between high- and low-acylsugar tomato lines. Crop Sci. Soc. Am. 50: 439-450.

Pereira GVN, Maluf WR, Gonçalves LD, Nascimento IR, et al. (2008). Seleção para alto teor de acilaçúcares em genótipos de tomateiro e sua relação com a resistência ao ácaro vermelho (Tetranychus evansi) e à traça (Tuta absoluta). Ciên. Agrotec. 32: 996-1004.

Resende JT, Maluf WR, Cardoso MG, Nelson DL, et al. (2002). Inheritance of acylsugar contents in tomatoes derived from an interspecific cross with the wild tomato Lycopersicon pennellii and their effect on spider mite repellence. Genet. Mol. Res. 1: 106-116.

Resende JTV, Maluf WR, Faria MV, Pfann AZ, et al. (2006). Acylsugars in tomato leaflets confer resistance to the south American tomato pinworm, Tuta absoluta Meyr. Sci. Agr. 63: 20-25.

Resende JTV, Maluf WR, Cardoso MG, Faria MV, et al. (2008). Resistance of tomato genotypes with high level of acylsugars to Tetranychus evansi Baker \& Pritchard. Sci. Agr. 65: 31-35.

Resende JTV, Maluf WR, Cardoso MG, Gonçalves LD, et al. (2009). Resistance of tomato genotypes to the silverleaf whitefly mediated by acylsugars. Hort. Bras. 27: 345-348.

Saeidi Z, Mallik B and Kulkarni RS (2007). Inheritance of glandular trichomes and two-spotted spider mite resistance in cross Lycopersicon esculentum "Nandi" and L. pennellii "LA2963". Euphytica 154: 231-238.

WPTC - World Processing Tomato Council (2011). World production estimate of 2011. Available at [http://www.wptc.to/ Releases-wptc.aspx]. Accessed November 23, 2011. 